\title{
Reproductive characteristics of Crioulo Lageano breed bulls (Bos taurus) at puberty
}

\author{
Paula Lorena Grangeira Souto ${ }^{1}$, Concepta McManus ${ }^{1}$, Fabiano Carminatti Zago ${ }^{2}$, Edison Martins ${ }^{3}$, \\ Joandes Henrique Fonteque ${ }^{4}$, Andrea Alves do Egito ${ }^{5}$, Alexandre Floriani Ramos ${ }^{6,7}$ \\ ${ }^{1}$ Department of Animal Sciences, Faculty of Agronomy and Veterinary Medicine, University of Brasília (UnB), Brasília, DF, \\ Brazil. \\ ${ }^{2}$ Santa Catarina State Agricultural Research and Rural Extension Agency Epagri), Florianópolis, SC, Brazil. \\ ${ }^{3}$ Brazilian Association of Breeders of the Crioulo Lageano Breed, Lages, SC, Brazil. \\ ${ }^{4}$ Veterinary Sciences Center, Santa Catarina State University (CAV/UDESC), Lages, SC, Brazil. \\ ${ }^{5}$ Embrapa Beef Cattle, Campo Grande, MS, Brazil. \\ ${ }^{6}$ Embrapa Genetic Resources and Biotechnology, Brasília, DF, Brazil.
}

\begin{abstract}
The aim of this research was to evaluate pubertal development characteristics of Crioulo Lageano breed bulls $(\mathrm{n}=10)$ using morphometric measurements and semen analysis, to identify factors that can be used to estimate age at puberty in this locally adapted breed. Monthly measurement of body weight and fortnightly measurement of scrotal circumference, chest girth, testicular length, width, thickness, and volume were recorded for each of the 10 Crioulo Lageano breed bulls, which were between 10 and 20 months old. During this period, semen samples were collected every two weeks using electroejaculation method and analyzed physically and morphologically. The ages of the appearance of first spermatozoa in the ejaculate (FSE), the first motile spermatozoa in the ejaculate (FSEM), seminal puberty (PUB) and total detachment between glans penis and prepuce (DPP) were ascertained. Crioulo Lageano bulls reached puberty at $14.1 \pm 2.0$ months old with lower weight and larger testicles than those of other bovine breeds. Similarly, the period from FSEM to PUB was shorter and the period from FSE to FSEM was longer than those reported for other breeds. The most important characteristics studied in order to estimate puberty age in Crioulo Lageano bulls were the measures of testicular length, width, and volume. These parameters can be used as criteria to select young bulls as sires.
\end{abstract}

Keywords: biometry, genetic resource, growth, sperm, testes.

\section{Introduction}

The Crioulo Lageano cattle found in Latin America are descendants of the Hamitic Longhorn cattle that were domesticated in Egypt about 4,000 B.C. These cattle were taken to south of Spain and were brought to Brazil during the colonization period. The Crioulo Lageano breed has been subjected to natural selection in the southern Brazilian State of Santa Catarina for over three centuries, and it acquired considerable genetic variability, which has allowed these cattle to thrive in the harsh environment of the Southern Highlands of Santa Catarina, the characteristics of which include rocky and acidic soils, high altitude, scarce food supplies and cold winters. Until the last century it was the predominant breed of cattle in the Lages region (Martins et al., 2009).

However, at the end of the 20th century, exotic breeds were imported and cross breeding of these with the locally adapted breeds produced excellent results. Since this period, the potential of maximum heterosis in the F1 generation has become well known and the results were attributed only to the imported breeds. Due the widespread increase in cross-breeding between these breeds, the population of the Crioulo Lageano breed has been decreasing drastically and a strong tendency persists toward replacement of local breeds with exotic breeds, mainly in southern Brazil (Spritze et al., 2003).

At the same time, it is well-known that locally adapted breeds are important genetic resources which may carry alleles of adaptive value and, in addition, may be useful in livestock breeding programs to contribute to the maintenance of genetic variation avoiding inbreeding depression (Egito et al., 2007; Kristensen et al., 2015).

Adaptability to extreme environmental conditions is mainly important in tropical areas, where most developing countries and approximately half of the livestock in the world are located. Thus, research to define reproductive characteristics becomes important to the breed's successful development and among these the puberty stage is highlighted.

During puberty, changes occur in the hypothalamic-pituitary axis that increases sensitivity to negative feedback from gonadal steroids, as well as a gradual rise in the gonadal sensibility to pituitary gonadotropins. Thereafter, spermatogenesis occurs and the reproductive stage begins for the bull. There are several definitions of puberty in scientific literature. In male cattle, the most commonly utilised definition is the age at which an ejaculate contains a minimum of 50 million total sperm cells and at least $10 \%$ of linear motility (Wolf et al., 1965). According to literature, this definition covers all of the others and is the easiest to be applied (Lunstra et al., 1978; Freneau et al., 2006).

\footnotetext{
${ }^{7}$ Corresponding author: alexandre.floriani@embrapa.br Phone: +55(61)3448-4724 
Age at puberty is an important determinant of reproductive efficacy and the knowledge regarding the timeframe of pubertal events may be a means to improve the reproductive efficiency of cattle by the selection of bulls which are potentially more fertile and precocious (Lunstra et al., 1978). In this interim, and considering the adaptive value of the genetic resources, the identification of factors that enable a more accurate and timely estimate of the age at which puberty occurs may contribute to genetic enhancement of local breeds.

Thus, the aim of this research was to evaluate the characteristics of pubertal development in Crioulo Lageano bulls, using morphometric measurements and semen analysis, to identify factors that can be used to estimate age at puberty.

\section{Materials and Methods}

Animal Care and Use Committee approval was not obtained for this study because the data were from an existing database dated and the experiment was carried out from November 2008 to October 2009 before the legal requirement of approval by an Animal Care and Use Committee.

\section{Bulls and semen collection}

This experiment was carried out in order to evaluate pubertal events of ten bulls of the Crioulo Lageano breed average of 10 months of age until 20 months of age. The bulls were raised in an extensive native grazing system near the city of Lages, Santa Catarina, Brazil (Lat Long -27.499345, -50.34878; elevation $884 \mathrm{M})$. According to Köppen Climate Classification the weather of the region is the $\mathrm{Cfb}$, meaning cold winter and mild summer. The average temperature during the winter was $20.7^{\circ} \mathrm{C}\left(15.3-27.2^{\circ} \mathrm{C}\right)$ and in summer was $24.0^{\circ} \mathrm{C}\left(19.7-29.1^{\circ} \mathrm{C}\right)$.

The grasslands are mainly composed by native grass species of the Andropogon lateralis Nees and Schizachyrium tenerum, nevertheless, during the winter food availability decreases due to the low temperatures, usually accompanied by frost (Zanin et al., 2009). The bulls were kept in the same environmental conditions until the end of the experiment and water and mineral supplements were provided ad libitum.

At thirty day intervals the bulls were weighed and at fifteen-day intervals the bulls were restrained in a squeeze chute for measurements of chest girth, using a measuring tape, and for scrotal measurements. The scrotal circumference was measured by holding the testes at the bottom of the scrotal sack and placing a scrotal tape around the widest point. Testicular length, testicular width and testicular thickness were measured using a Vernier Caliper. Testicular volume was calculated using the average values of length and width of both testicles by the following equation: $\mathrm{V}=$ $2[(\mathrm{r} 2) . \pi \mathrm{h}]$ where $\mathrm{r}=$ width $/ 2, \mathrm{~h}=$ length, e $\pi=3.14$
(Colégio Brasileiro de Reprodução Animal - CBRA, 1998; Sosa et al., 2002; Torres-Júnior and Henry, 2005; Siddiqui et al., 2008).

On the same day of the measurements, the semen was collected from each bull once every two weeks using a manually operated electro-ejaculator (Duboi ${ }^{\circledR}$, Campo Grande, MS, Brazil). In summary, electrical stimuli were applied in a continuous rhythm and collection of semen samples began when the preejaculatory fluids trickling from the glans penis become opaque and was concluded when the fluids again turned clear (Althouse, 2007; Menegassi et al., 2015).

Also, the degree of separation of the foreskin of the penis from the glans was assessed and the average age at which the bulls showed total detachment (DPP) was ascertained thereby (Freneau et al., 1995). Additionally, the ages of the occurrence of first spermatozoa in the ejaculate (FSE), first motile spermatozoa in the ejaculate (FSEM) and seminal puberty (PUB) were determined. Puberty was defined as the age at which each bull first produced an ejaculate containing at least $50 \times 10^{6}$ total sperm with at least $10 \%$ progressive motility (Wolf et al., 1965).

\section{Evaluation of semen}

The semen samples were assessed for total motility (0-100\%) and vigor (0-5) using a phasecontrast microscope (Olympus BX50), 200X magnification (CBRA, 2013). For this, a drop of semen was placed on a slide preheated to $37^{\circ} \mathrm{C}$ and covered with a warmed cover slip. Sperm concentration $\left(\times 10^{6} / \mathrm{ml}\right)$ was calculated using a Neubauer chamber and ejaculate volume was measured in milliliters. For sperm morphology, wet preparations of semen fixed in buffered isotonic formal-saline $(1: 200)$ were assessed under phase-contrast microscopy (Olympus BX50; 1,000X magnification), counting 200 cells per sample $(\%$, oil immersion) classified on major defects and minor defects (Teixeira et al., 2011; CBRA, 2013; Moreira et al., 2016).

\section{Statistical analysis}

Mean values and standard deviations were calculated and compared by means of the TukeyKramer test, using SAS $^{\circledR}$ Enterprise Guide 5.1, 2012 software. Differences were considered statistically significant when $\mathrm{P}<0.05$. The Shapiro-Wilk test and Bartlett test showed that the data lacked normality and homogeneity, respectively. Due to this, the Glimmix procedure was utilized and the mean of least squares were adjusted by the Tukey-Kramer test. Spearman correlations were produced for the semen parameters and morphometric characteristics according to age at puberty. A multiple regression analysis used the morphometric measures to identify the best model to illustrate the development of puberty. The variables were selected after several steps in the Multiple Linear 
Regression. Those variables that did not present a significant source of variation $(\mathrm{P}>0.15)$ were removed. At the last step, the model contained only the principal effects and relevant variables. Furthermore, these variables create the vectors of components for Principal Component Analysis in which each factor is calculated based on total variation among all individuals. Finally, a logistic regression model was created to analyze the behavior of variables during puberty and to seek some probabilistic relation between a group of independent variables and the categorical variable, i.e., pubertal $=1$ or not pubertal $=0$. In this analysis, the binomial distribution and the maximum likelihood estimation method (MLE) were utilized. Only the significant variables were included in the model. The evaluation of the adjusted model was verified using a Hosmer and Lemeshow Goodness-of-Fit test which indicated that the model is valid $(\mathrm{P}=0.856)$.

\section{Results}

The corporal and testicular growth characteristics and the physical and morphological aspects of the ejaculate of the bulls throughout this experiment are shown in Table 1, which shown that there were significant differences among the ages studied. The corporal development of the Crioulo Lageano bulls was satisfactory, as demonstrated by the progressive increase $(\mathrm{P}<0.05)$ in the values of the morphometric characteristics over time. Two bulls did not reach puberty until the end of the experimental period and the other eight bulls reached puberty at 12 , $13,13,13,14,14,16$ and 18 months of age, respectively, with a mean and standard deviation of $14.1 \pm 2.0$ months of age. The average weight gain per day was $0.416 \mathrm{~kg}$, ranging from $0.200 \mathrm{~kg}$ to $0.727 \mathrm{~kg}$.

Table 2 shows the analysis of the correlation between age and corporal and testicular characteristics, as well as the physical and morphologic aspects of semen in Crioulo Lageano bulls during the puberty phase. There was a strong correlation $(\mathrm{P}<0.05)$ between age and all morphometric measurements. There was a significant increase in ejaculate volume from 10 to 18 months of age. The characteristics ejaculate volume $(\rho=0.42)$ and spermatozoa per milliliter $(\rho=0.54)$ showed significant correlation with age. The major defects showed a negative correlation with age $(\rho=-0.54)$, whereas minor defects correlated positively $(\rho=0.66 ; \mathrm{P}<0.05)$. It is noteworthy that there is high negative correlation between motility and total defects $(\rho=-0.73)$ and major defects $(\rho=-0.67)$. These associations are found during puberty in bulls and they are part of the process of reproductive development to reach sexual maturity (Amann et al., 2000; Freneau et al., 2006). Only after 13 months of age was there a significant difference $(\mathrm{P}$ $<0.05)$ in the concentration of sperm per milliliter and per ejaculate. There were significant increases in spermatic motility and vigor starting at 12 months of age $(\mathrm{P}<0.05)$.

Figure 1 shows the percentage of puberty events in relation to age of the bulls with an average age of FSE, FSEM, PUB and DPP of $11.7 \pm 1.0 ; 14.0$ $\pm 1.9 ; 14.1 \pm 2.0 ; 17.0 \pm 1.8$ months of age, respectively.

The Principal Component Analysis of morphometric characteristics that were selected by multiple regression analysis is shown in the Fig. 2 and the Table 3 contains the first two eigenvectors of the correlation matrix with the factor load of each variable with regard to the corresponding component. The first column of the Table 3 corresponds to the first principal component (labeled Factor 1), and the second column to the second principal component (labeled Factor 2). This analysis indicates that most of the bulls had an early onset of puberty, reaching it with relatively lower weight and larger testes.

Figure 3A illustrates the Receiver Operating Characteristic (ROC) curve for the logistic regression model. The Area Under the Curve (AUC) corresponds to approximately 95 percentage points, demonstrating exceptional discriminating power, as described (Hosmer and Lemeshow, 2000). This indicates that the proportion of predicted positives to bulls that are truly positives, i.e., those that really are pubescent, is highly reliable. Figure 3B shows a predicted probability curve generated using a logistical regression analysis, with 95\% confidence limit, and determines that the effects of testicular measures are significant and sufficient for the model fit. Other characteristics of corporal growth, such as chest girth, scrotal circumference and body weight, although included in the model for the original study design, have not provided a significant contribution. 
Table 1. Mean and standard deviation of body and testicular biometric parameters in Crioulo Lageano bulls raised in natural conditions.

\begin{tabular}{|c|c|c|c|c|c|c|c|c|c|}
\hline & \multicolumn{9}{|c|}{ Age (months) } \\
\hline & 10 & 11 & 12 & 13 & 14 & 15 & 16 & 17 & 18 \\
\hline BW & $192.9 \pm 57.3^{\mathrm{c}}$ & $213.05 \pm 54.8^{\mathrm{bc}}$ & $231.0 \pm 51.6^{\mathrm{abc}}$ & $254.2 \pm 52.7^{\mathrm{ab}}$ & $256.7 \pm 48.5^{\mathrm{ab}}$ & $257.8 \pm 47.4^{\mathrm{a}}$ & $265.7 \pm 52.0^{\mathrm{a}}$ & $271.7 \pm 55.8^{\mathrm{a}}$ & $273.1 \pm 46.6^{\mathrm{a}}$ \\
\hline $\mathrm{CG}$ & $66.9 \pm 5.7^{\mathrm{d}}$ & $69.4 \pm 4.8^{\mathrm{dc}}$ & $71.5 \pm 4.4^{\mathrm{bc}}$ & $74.3 \pm 4.2^{\mathrm{ab}}$ & $75.3 \pm 3.8^{\mathrm{a}}$ & $75.7 \pm 2.9^{\mathrm{a}}$ & $76.5 \pm 3.2^{\mathrm{a}}$ & $76.6 \pm 4.0^{\mathrm{a}}$ & $77.3 \pm 3.4^{\mathrm{a}}$ \\
\hline $\mathrm{SC}$ & $21.6 \pm 2.5^{\mathrm{d}}$ & $23.2 \pm 2.4^{\mathrm{dc}}$ & $24.9 \pm 2.4^{\mathrm{bc}}$ & $26.3 \pm 2.7^{\mathrm{ab}}$ & $26.9 \pm 2.8^{\mathrm{ab}}$ & $27.3 \pm 3.0^{\mathrm{a}}$ & $27.6 \pm 3.3^{\mathrm{a}}$ & $28.5 \pm 3.5^{\mathrm{a}}$ & $28.1 \pm 3.4^{\mathrm{a}}$ \\
\hline $\mathrm{TL}$ & $7.2 \pm 1.0^{\mathrm{e}}$ & $7.8 \pm 0.8^{\mathrm{de}}$ & $8.3 \pm 0.9^{\mathrm{dc}}$ & $9.0 \pm 1.0^{\mathrm{bc}}$ & $9.3 \pm 1.1^{\mathrm{ab}}$ & $9.6 \pm 1.1^{\mathrm{ab}}$ & $9.9 \pm 1.3^{\mathrm{ab}}$ & $10.2 \pm 1.4^{\mathrm{a}}$ & $10.3 \pm 1.1^{\mathrm{a}}$ \\
\hline TW & $3.9 \pm 0.5^{\mathrm{e}}$ & $4.2 \pm 0.5^{\mathrm{de}}$ & $4.5 \pm 0.5^{\mathrm{dc}}$ & $4.7 \pm 0.5^{\mathrm{bc}}$ & $4.8 \pm 0.5^{\mathrm{abc}}$ & $5.0 \pm 0.5^{\mathrm{ab}}$ & $5.2 \pm 0.6^{\mathrm{ab}}$ & $5.3 \pm 0.7^{\mathrm{a}}$ & $5.3 \pm 0.5^{\mathrm{a}}$ \\
\hline TT & $4.0 \pm 0.5^{\mathrm{d}}$ & $4.3 \pm 0.6^{\mathrm{dc}}$ & $4.6 \pm 0.6^{\mathrm{bc}}$ & $4.9 \pm 0.6^{\mathrm{ab}}$ & $5.0 \pm 0.7^{\mathrm{ab}}$ & $5.1 \pm 0.7^{\mathrm{ab}}$ & $5.2 \pm 0.8^{\mathrm{a}}$ & $5.4 \pm 0.8^{\mathrm{a}}$ & $5.3 \pm 0.7^{\mathrm{a}}$ \\
\hline TV & $722.3 \pm 273.2^{f}$ & $904.9 \pm 279.3^{\mathrm{ef}}$ & $1085.5 \pm 310.8^{\mathrm{de}}$ & $1302.1 \pm 371.9^{\mathrm{dc}}$ & $1409.7 \pm 427.9^{\mathrm{bcd}}$ & $1576.1 \pm 474.2^{\mathrm{abc}}$ & $1715.6 \pm 562.7^{\mathrm{ab}}$ & $1859.7 \pm 624.1^{\mathrm{a}}$ & $1897.3 \pm 470.3^{\mathrm{a}}$ \\
\hline EV & $1.3 \pm 0.9^{\mathrm{b}}$ & $1.4 \pm 0.8^{\mathrm{b}}$ & $2.4 \pm 1.6^{\mathrm{ab}}$ & $2.9 \pm 1.5 \mathrm{a}$ & $3.1 \pm 1.7^{\mathrm{a}}$ & $2.8 \pm 0.9^{\mathrm{a}}$ & $2.7 \pm 1.5^{\mathrm{a}}$ & $2.4 \pm 0.9^{\mathrm{ab}}$ & $3.1 \pm 1.0^{\mathrm{a}}$ \\
\hline $\mathrm{Sp} / \mathrm{Ej}$ & $0 \pm 0^{\mathrm{ab}}$ & $3.4 \pm 10.3^{\mathrm{ab}}$ & $6.8 \pm 21.5^{\mathrm{ab}}$ & $78.3 \pm 172.2^{\mathrm{b}}$ & $152.1 \pm 373.2^{\mathrm{ab}}$ & $229.2 \pm 546.5^{\mathrm{ab}}$ & $418.9 \pm 871.4^{\mathrm{ab}}$ & $357.0 \pm 517.4^{\mathrm{ab}}$ & $817.0 \pm 740.2^{\mathrm{a}}$ \\
\hline $\mathrm{Sp} / \mathrm{ml}$ & $0 \pm 0^{\mathrm{ab}}$ & $1.7 \pm 5.2^{\mathrm{ab}}$ & $2.2 \pm 6.9^{\mathrm{ab}}$ & $18.6 \pm 41.7^{\mathrm{b}}$ & $33.8 \pm 66.4^{\mathrm{b}}$ & $72.3 \pm 152.1^{\mathrm{b}}$ & $148.5 \pm 242.2^{\mathrm{ab}}$ & $138.5 \pm 200.2^{\mathrm{ab}}$ & $272.0 \pm 228.6^{\mathrm{a}}$ \\
\hline Mot & - & $0 \pm 0^{\mathrm{abc}}$ & $3.8 \pm 7.4^{\mathrm{c}}$ & $8.3 \pm 11.1 \mathrm{c}$ & $35.0 \pm 18.4^{\mathrm{ab}}$ & $25.8 \pm 15.3^{\mathrm{b}}$ & $42.9 \pm 21.4^{\mathrm{ab}}$ & $52.3 \pm 14.7^{\mathrm{a}}$ & $45.0 \pm 17.7^{\mathrm{ab}}$ \\
\hline Vig & - & $0 \pm 0^{\mathrm{abcd}}$ & $0.1 \pm 0.4^{\mathrm{d}}$ & $0.5 \pm 0.7^{\mathrm{cd}}$ & $1.5 \pm 0.9^{\mathrm{ab}}$ & $1.2 \pm 0.7^{\mathrm{bc}}$ & $2.2 \pm 1.1^{\mathrm{a}}$ & $2.5 \pm 0.8^{\mathrm{a}}$ & $2.5 \pm 0.5^{\mathrm{a}}$ \\
\hline MAD & - & $71.3 \pm 4.8^{\mathrm{a}}$ & $67.1 \pm 19.7^{\mathrm{a}}$ & $61.9 \pm 18.7^{\mathrm{a}}$ & $39.0 \pm 21.7^{\mathrm{ab}}$ & $37.4 \pm 25.1^{\mathrm{ab}}$ & $26.6 \pm 16.0^{\mathrm{b}}$ & $26.3 \pm 22.4^{\mathrm{b}}$ & $32.8 \pm 23.9^{\mathrm{ab}}$ \\
\hline MID & - & $6.0 \pm 6.0^{\mathrm{a}}$ & $5.1 \pm 3.3^{\mathrm{a}}$ & $10.0 \pm 8.3^{\mathrm{a}}$ & $9.9 \pm 6.7^{\mathrm{a}}$ & $17.4 \pm 12.5^{\mathrm{a}}$ & $18.2 \pm 11.0^{\mathrm{a}}$ & $15.8 \pm 9.4^{\mathrm{a}}$ & $20.1 \pm 16.3^{\mathrm{a}}$ \\
\hline TD & - & $77.3 \pm 5.6^{\mathrm{a}}$ & $72.5 \pm 20.4^{\mathrm{a}}$ & $72.3 \pm 19.0^{\mathrm{a}}$ & $48.8 \pm 18.7^{\mathrm{a}}$ & $54.6 \pm 27.6^{\mathrm{a}}$ & $44.6 \pm 22.5^{\mathrm{a}}$ & $41.6 \pm 26.0^{\mathrm{a}}$ & $52.6 \pm 23.1^{\mathrm{a}}$ \\
\hline
\end{tabular}

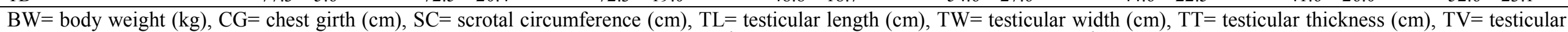

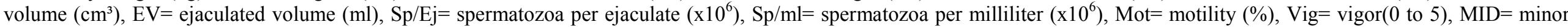
defects $(\%), M A D=$ major defects $(\%), T D=$ total defects $(\%)$.Means with different superscript letters are significantly different according to Tukey test $(5 \%)$. 
Souto et al. Puberty of locally adapted Crioulo Lageano bulls.

Table 2. Correlation coefficients between age and body development, testicular characteristics and physical and morphological aspects of semen of Crioulo Lageano bulls at pubertal period.

\begin{tabular}{|c|c|c|c|c|c|c|c|c|c|c|c|c|c|c|c|c|}
\hline & Age & BW & CG & $\mathrm{SC}$ & TL & TW & $\mathrm{TT}$ & EV & $\mathrm{Sp} / \mathrm{Ej}$ & TV & $\mathrm{Sp} / \mathrm{ml}$ & Mot & Vig & MAD & MID & TD \\
\hline Age & - & $* 0.71$ & $* 0.74$ & $* 0.82$ & $* 0.84$ & $* 0.80$ & $* 0.78$ & $* 0.42$ & 0.16 & $* 0.81$ & $* 0.54$ & -0.15 & 0.38 & $*_{-}-0.54$ & $* 0.66$ & -0.26 \\
\hline BW & & - & *0.94 & $* 0.87$ & $* 0.88$ & $* 0.86$ & *0.89 & $* 0.48$ & -0.15 & $* 0.87$ & $* 0.47$ & -0.45 & -0.24 & -0.43 & $* 0.63$ & -0.16 \\
\hline $\mathrm{CG}$ & & & - & $* 0.84$ & $* 0.83$ & $* 0.83$ & $* 0.85$ & $* 0.57$ & 0.00 & $* 0.83$ & $* 0.56$ & -0.22 & -0.09 & -0.46 & $* 0.74$ & -0.15 \\
\hline $\mathrm{SC}$ & & & & - & *0.93 & $* 0.97$ & *0.97 & 0.24 & -0.11 & $* 0.96$ & 0.34 & -0.11 & 0.30 & $*_{-} 0.62$ & $* 0.70$ & -0.30 \\
\hline TL & & & & & - & $* 0.97$ & *0.95 & $* 0.33$ & -0.04 & *0.98 & $* 0.54$ & 0.01 & 0.09 & $*_{-} 0.55$ & $* 0.69$ & -0.27 \\
\hline TW & & & & & & - & $* 0.98$ & 0.24 & -0.11 & *0.99 & 0.43 & 0.11 & 0.12 & $*_{-0.65}$ & $* 0.68$ & -0.36 \\
\hline TT & & & & & & & - & 0.26 & -0.15 & $* 0.97$ & 0.38 & 0.20 & 0.12 & $*_{-0.66}$ & $* 0.76$ & -0.32 \\
\hline EV & & & & & & & & - & 0.31 & 0.27 & 0.28 & -0.01 & -0.60 & -0.21 & 0.37 & -0.07 \\
\hline $\mathrm{Sp} / \mathrm{Ej}$ & & & & & & & & & - & -0.06 & $* 0.97$ & -0.44 & 0.30 & -0.28 & 0.23 & -0.14 \\
\hline TV & & & & & & & & & & - & $* 0.50$ & 0.20 & 0.12 & $*_{-} 0.64$ & $* 0.70$ & -0.36 \\
\hline $\mathrm{Sp} / \mathrm{mL}$ & & & & & & & & & & & - & -0.31 & 0.30 & -0.22 & 0.23 & -0.10 \\
\hline Mot & & & & & & & & & & & & - & 0.18 & -0.67 & 0.44 & -0.73 \\
\hline Vig & & & & & & & & & & & & & - & 0.12 & 0.36 & 0.30 \\
\hline MAD & & & & & & & & & & & & & & - & -0.49 & $* 0.87$ \\
\hline MID & & & & & & & & & & & & & & & - & -0.09 \\
\hline TD & & & & & & & & & & & & & & & & \\
\hline
\end{tabular}

$\mathrm{BW}=$ body weight $(\mathrm{kg}), \mathrm{CG}=$ chest girth $(\mathrm{cm}), \mathrm{SC}=$ scrotal circumference $(\mathrm{cm}), \mathrm{TL}=$ testicular length $(\mathrm{cm}), \mathrm{TW}=$ testicular width $(\mathrm{cm}), \mathrm{TT}=$ testicular thickness $(\mathrm{cm}), \mathrm{TV}=$ testicular volume $\left(\mathrm{cm}^{3}\right), \mathrm{EV}=$ ejaculated volume $(\mathrm{ml})$, $\mathrm{Sp} / \mathrm{Ej}=$ spermatozoa per ejaculate $\left(\mathrm{x} 10^{6}\right), \mathrm{Sp} / \mathrm{ml}=$ spermatozoa per milliliter $\left(\times 10^{6}\right)$, Mot= motility $(\%)$, Vig= vigor (0 to 5$), \mathrm{MID}=$ minor defects $(\%), \mathrm{MAD}=$ major defects $(\%), \mathrm{TD}=$ total defects $(\%)$. Values highlighted with an asterisk are significant by Spearman correlation analysis $(5 \%)$.

Table 3. Principal Component Analysis: factor pattern.

\begin{tabular}{|c|c|c|}
\hline Variable & Factor 1 & Factor 2 \\
\hline Age & 0.75 & 0.58 \\
\hline Body weight & 0.87 & -0.47 \\
\hline Chest girth & 0.92 & -0.27 \\
\hline Length & 0.93 & 0.14 \\
\hline Width & 0.93 & 0.10 \\
\hline
\end{tabular}

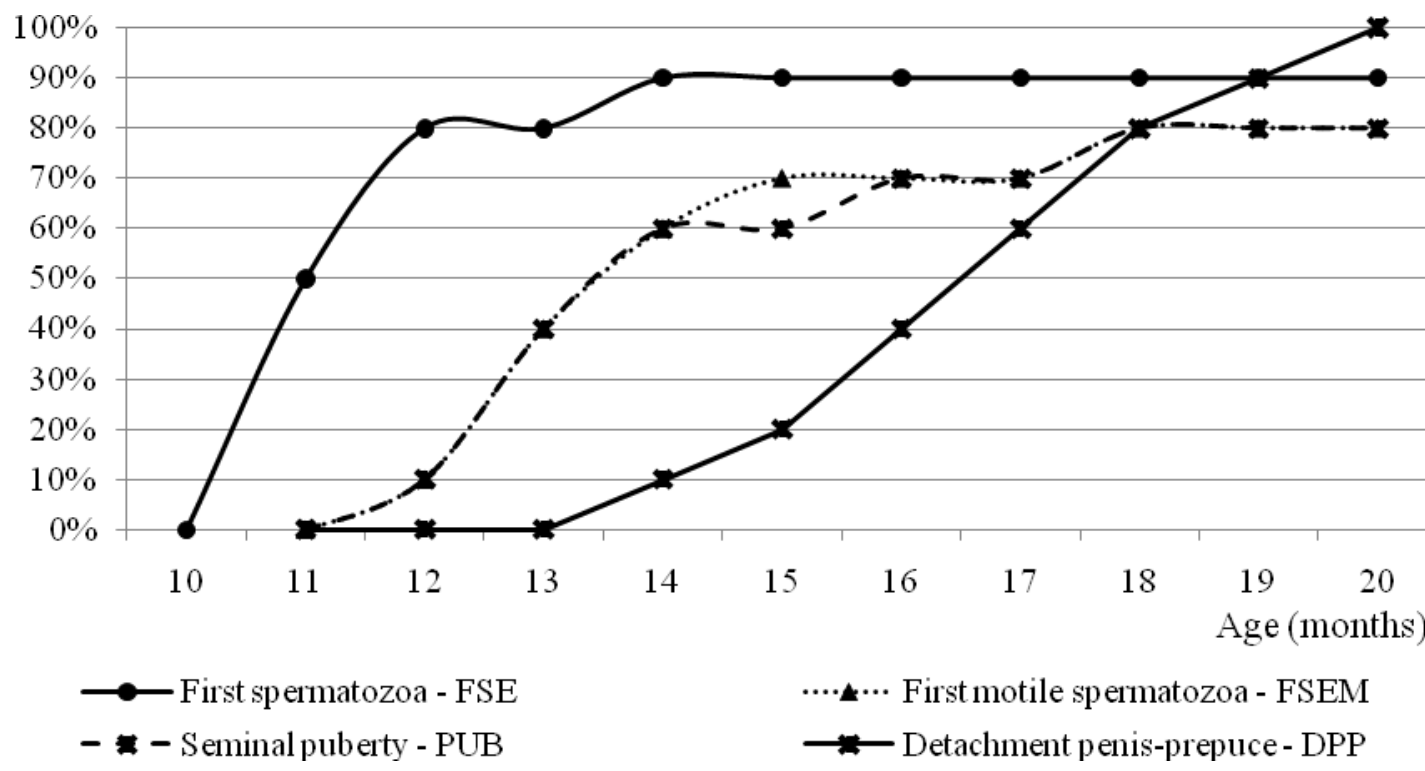

Figure 1. Percentage of Crioulo Lageanos bulls that reached the reproductive events according to age. 


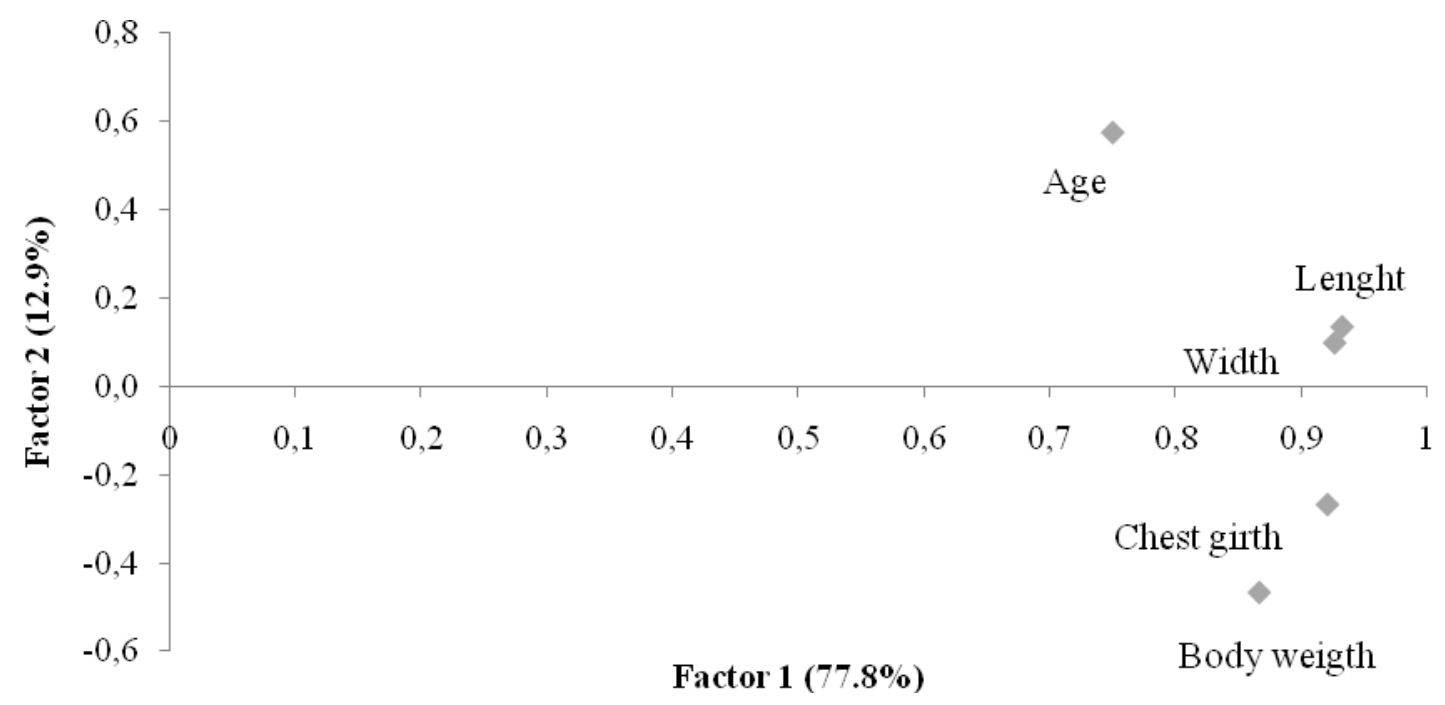

Figure 2. Principal Component Analysis of morphometric characteristics of Crioulo Lageano bulls at pubertal period.

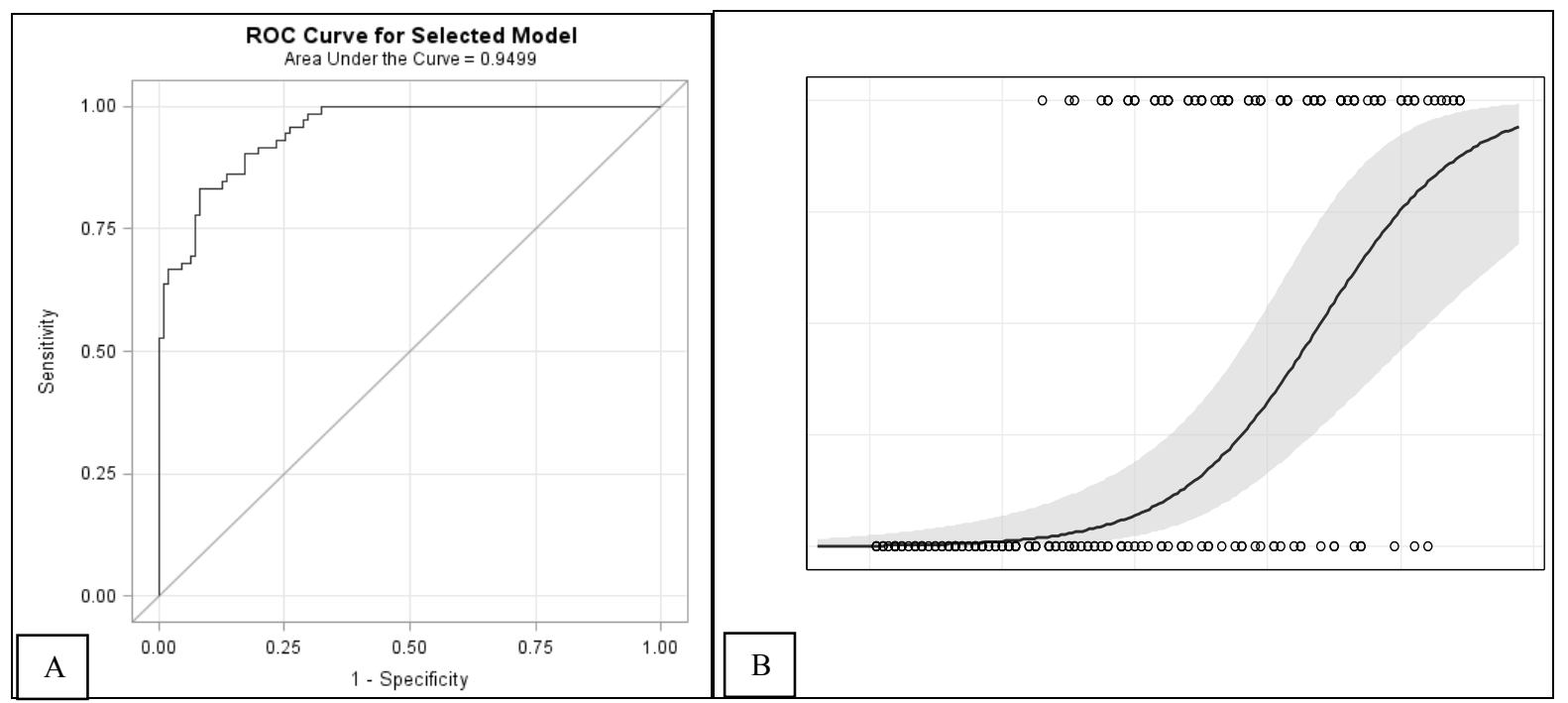

Figure 3. A) Receiver Operating Characteristic (ROC) curve. B) Logistic regression curve showing the occurrence probability curve of puberty in Crioulo Lageano male cattle according to age and morphometry.

\section{Discussion}

The daily weight gain of Crioulo Lageano bulls was similar to that reported by Freneau et al. (2006) in Nellore bulls $(0.510 \mathrm{~kg})$, which were also kept exclusively in a pasture system. Wolf et al. (1965) reported a greater average daily weight gain of $0.640 \mathrm{~kg}$ to $1.360 \mathrm{~kg}$ in Angus and Hereford breeds, which reached puberty on average at 12 months of age. Brito et al. (2012) recorded daily gains achieved between 6 and 16 months of age about 1 to $1.6 \mathrm{~kg}$ in Angus and crossbred Angus with Charolais. However, the above mentioned authors provided supplemented feed to the bulls, whereas in this research, they were kept only on a natural pasture throughout the entire experiment, and these nutritional conditions were sufficient and compatible with the reproductive development of the bulls.

The Crioulo Lageano bulls reached puberty at $14.1 \pm 2.0$ months of age. Fields et al. (1982) found that young bulls of the Angus and Brahman breeds at puberty were, respectively, 15.7 and 15.9 months old. Troconiz et al. (1991) reported that Nellore bulls reached puberty at 18.5 months of age while Unanian et al. (2000) reported greater precocity in Nellore bulls, with an average age of 13.6 months at puberty. In work of Brito et al. (2004), age at puberty ranged from 17.6 to 22.4 months in Zebu breeds and Martins et al. (2011) found a slightly smaller range, from 17 to 19 months, in Gir bulls.

The results in this experiment shown a constant rate of corporal and testicular growth which is 
compatible with that of Taurine and also Zebu bulls of similar ages (Unanian et al., 2000; Moura et al., 2002). The seminal characteristics showed relatively high standard deviations due to the difference in age at the onset of sperm production among the bulls. The fact that this is a breed which has been subjected only to natural selection can explain this variation, but it is also known that this variation is typical of the pubertal phase of bulls when there is more and less precocious bulls in the same herd.

In the sperm morphology analysis, there was a significant decrease in major defects. Despite the increase observed in the results of minor defects and decrease in total defects, these variables showed no statistical difference throughout the experimental period. As occurred in a study conducted by Silva (2007) by the end of the experiment the bulls' semen still showed rates of total defects exceeding 30\% whereas in another study all beef bulls (Angus and Angus x Charolais) were mature by 462 days of age presenting $76.5 \pm 18.4$ morphologically normal spermatozoa (\%; Brito et al., 2012). According to the Brazilian College of Animal Reproduction (CBRA, 2013) seminal sexual maturity only occurs when the bull produces the first ejaculate with a maximum of $20 \%$ of major defects and $30 \%$ total defects, and this generally occurs after puberty ends (Brito et al., 2004; Freneau, 2011; Teixeira et al., 2011).

According the occurrence of puberty events in relation to age of the bulls, the founds showed that the DPP occurred at $17.0 \pm 1.8$ months of 18 months of age with a scrotal circumference of $28.1 \pm 3.4 \mathrm{~cm}$, while in other research (Torres-Júnior and Henry, 2005), 79.7\% of young Guzera bulls reached the same age with a scrotal circumference between 23 and $25.5 \mathrm{~cm}$. These observations indicate probable genetic and environmental differences between the Crioulo Lageano and other cattle breeds.

At 14 months old 60 age, however, this was still slightly earlier than the age reported by Freneau et al. (2006) of $18.1 \pm 1.9$ months in Nellore bulls. The time elapsed between FSEM and PUB was of 0.13 months, and between FSE and FSEM was 2.3 months, the latter being longer than what was described by Freneau et al. (2006). At 16 months old, 100\%, 88\% and $88 \%$ of the bulls had show FSE, FSEM and PUB, respectively. Freneau et al. (2006) reported a smaller proportion at this age, 91.4, 82.6 and $73.9 \%$, respectively. In this study, $80 \%$ of young bulls had reached puberty by $\%$ of the bulls reached PUB, however, only $10 \%$ showed complete detachment between glans penis and prepuce. Only at 18 months old PUB and DPP events had occurred in $80 \%$ of bulls. In Nellore bulls the DPP was $18.1 \pm 1.9$ months of age and also did not influence the onset of other reproductive events in these bulls (Freneau et al., 2006).

Based on facts above discussed and that the Crioulo Lageano breed was only submitted to the pressure of natural selection for over three centuries (Spritze et al., 2003), it is suggested that the interval of six months between the onset of puberty in the most and least precocious bull, observed in this experiment, indicates the possibility of selecting those bulls which are potentially more precocious and fertile.

In statistical analysis, when two measures have similar origin in multiple regression analysis, such as testicular volume and the variables testicular length, width and thickness, the variance inflation factor (VIF) of one generally influences the others. The VIF indicates how much the variance of an estimated regression coefficient is increased due to collinearity. The collinearity diagnostics can be checked by the variance inflation factor and by the proportion analysis of variation that each characteristic imprints on another. After these analyses, the variables were selected that showed variance inflation factors of less than 0.15 , namely: age, weight, chest girth and testicular measurements of length and width.

The importance of a Principal Component is evaluated according to its contribution, that is, the proportion of total variance explained by the factor, but there is no minimum parameter for all situations. According to Regazzi (2000), in several fields of knowledge, the number of factors considered has been the one that accumulates $70 \%$ or more of total variance. In this study, the first two principal components account for over $90.8 \%$ of the total variation in the data.

Examining the coefficients that make up the eigenvectors of the Principal Components Analysis, it can be observed that Factor 1 has large positive loadings for all variables. Its correlation with variables of length and width $(0.93)$ is notably high, followed by characteristics of chest girth and body weight. This indicates that most of the bulls had an early onset of puberty, reaching it with relatively lower weight and larger testes. Similarly, Freneau et al. (2006) reported that young Nellore bulls with larger testes reached puberty earlier. However, Baker et al. (1988) using a similar statistical model to the one utilized in this research and found that most of the variation $(63 \%)$ between crossbred bulls of the Angus, Brahman, Hereford, Holstein, and Jersey breeds was attributable to weight and height, inasmuch as shorter and heavier bulls showed a greater probability of reaching puberty precociously, which differs from the results of this study, wherein those bulls with lower body weights and larger testes were the most precocious. In two other studies the growth and pubertal development of F1 bulls produced from Bos taurus and Bos indicus breeds were characterized. Regardless of the sire breed, bulls reached puberty earlier and slightly heavier than Crioulo Lageano bulls of this study and with a scrotal circumference of approximately $28 \mathrm{~cm}$ (Lunstra and Cundiff, 2003; Casas et al., 2007). It's important to highlight that those F1 bulls were fed a supplemented diet while the Crioulo Lageano bulls were kept on natural pasture. Besides the genetic differences between breeds, diet also contributes to the rates of weight gain.

Many studies seek to identify reproductive characteristics that enable a better forecast of the onset of puberty and of reproductive potential in bulls. Some authors report that scrotal circumference may be useful in selecting bulls due to its good correlation with age at puberty and to the ease of obtaining this measurement 
(Lunstra et al., 1978; Menegassi et al., 2011). Brito et al. (2004) also suggested that scrotal circumference can be a good indicator to predict puberty for Nellore and Canchim bulls due to the better sensitivity/specificity relation shown in the ROC curve. According to these authors, scrotal circumference of $19 \mathrm{~cm}$ for Nellore bulls and $24 \mathrm{~cm}$ for Canchim bulls, at 12 months of age, may be a useful measure for selecting precocious bulls Testicular volume is identified in some studies as a parameter that minimizes errors resulting from the measurement of scrotal circumference when, for instance, the testes are of different shapes and also due to the possibility this characteristic be calculated from two-dimensional measurements making it a more reliable measure. Unanian et al. (2000) concluded in their study that the combination of the scrotal circumference and testicular volume characteristics promotes greater accuracy for assessing reproductive potential in Nellore bulls. Furthermore, Brito et al. (2012) conducted a study in which the characteristics of age, body weight, scrotal circumference and testicular volume were identified as good predictors of puberty in Angus and crossbred bulls.

In this study we suggest that measurements close to a testicular volume of $1,363 \mathrm{~cm}^{3}$, a testicular length of $9 \mathrm{~cm}$, testicular width and thickness of about $4.8 \mathrm{~cm}$, each may be useful in predicting puberty in Crioulo Lageano bulls. Within this context it is worth noting, though, that these dimensions were recorded between 13 and 14 months of age, with average scrotal circumference of $26.6 \mathrm{~cm}$.

The Crioulo Lageano bulls reached puberty at 14 months of age on average, ranging from 12 to 18 months, and showing good testicular development. The presence of more and less precocious individuals in the herd suggests that the breed has good potential for genetic improvement regarding this characteristic. It was ascertained that the characteristics of testicular size, particularly length, width, and testicular volume, were the most relevant for estimating age at puberty in Crioulo Lageano bulls.

\section{Acknowledgments}

To the Brazilian Criollo Lageano Cattle Breeders Association (ABCCL).

\section{References}

Althouse G. 2007. Artificial insemination. In: Schatten $\mathrm{H}$, Constantinescu GM. Comparative Reproductive Biology. Ames: Blackwell Publishing. pp. 159-160.

Amann RP, Seidel GE, Mortimer RG. 2000. Fertilizing potential in vitro of semen from young beef bulls containing a high or low percentage of sperm with a proximal droplet. Theriogenology, 54:1499-1515.

Baker JF, Stewart TS, Long CR, Cartwright TC. 1988. Multiple regression and principal components analysis of puberty and growth in cattle. J Anim Sci, 66:2147-2158.

Brito LFC, Silva AEDF, Barbosa RT, Kastelic JP.

2004. Testicular thermoregulation in Bos indicus, crossbred and Bos taurus bulls: relationship with scrotal, testicular vascular cone and testicular morphology, and effects on semen quality and sperm production. Theriogenology, 61:511-528.

Brito LFC, Barth AD, Wilde RE, Kastelic JP. 2012. Effect of growth rate from 6 to 16 months of age on sexual development and reproductive function in beef bulls. Theriogenology, 77:1398-1405.

Casas E, Lunstra DD, Cundiff L V., Ford JJ. 2007. Growth and pubertal development of F1 bulls from Hereford, Angus, Norwegian Red, Swedish Red and White, Friesian, and Wagyu sires. J. Anim. Sci. 85:2904-2909.

Colégio Brasileiro de Reprodução Animal. 1998. Manual para Exame Andrológico e Avaliação de Sêmen Animal. 2nd. Belo Horizonte, MG: CBRA. pp. 49.

Colégio Brasileiro de Reprodução Animal. 2013. Manual para Exame Andrológico e Avaliação de Sêmen anImal. 3rd. Belo Horizonte, MG: CBRA. pp. 104.

Egito A, Paiva S, Albuquerque MS, Mariante A, Almeida L, Castro S, Grattapaglia D. 2007. Microsatellite based genetic diversity and relationships among ten Creole and commercial cattle breeds raised in Brazil. BMC Genet, 8:83. doi.org/10.1186/14712156-8-83.

Fields MJ, Burns WC, Warnick AC. 1982. Aspects of the sexual development of Brahma versus Angus bulls in florida. Theriogenology, 18:17-31.

Freneau GE, Guimarães JD, Vale Filho VR. 1995. Desprendimento puberal entre pênis e prepúcio em touros europeus e mestiços F1. Rev Bras Reprod Anim, 19:153-160.

Freneau GE, Vale Filho VR, Marques Jr AP, Maria WS. 2006. Puberdade em touros Nelore criados em pasto no Brasil: características corporais, testiculares e seminais e de índice de capacidade andrológica por pontos. Arq Bras Med Vet Zootec, 58:1107-1115.

Freneau GE. 2011. Aspectos da morfologia espermática em touros. Rev Bras Reprod Anim, 35:160170.

Hosmer DW, Lemeshow S. 2000. Applied Logistic Regression. New York, NY: Wiley. pp.303.

Kristensen TN, Hoffmann AA, Pertoldi C, Stronen AV. 2015. What can livestock breeders learn from conservation genetics and vice versa? Front Genet, 5:112. doi: 10.3389/fgene.2015.00038.

Lunstra DD, Ford JJ, Echternkamp SE. 1978. Puberty in beef bulls: hormone concentrations, growth, testicular development, sperm production and sexual aggressiveness in bulls of different breeds. J Anim Sci, 46:1054-1062.

Lunstra DD, Cundiff LV. 2003. Growth and pubertal development in Brahman-, Boran-, Tuli-, Belgian Blue-, Hereford- and Angus-sired F1 bulls. J Anim Sci, 81:1414-1426.

Martins JAM, Souza FA, Ferreira MBD, Gonçalves PEM, Emerick LL, Dias JC, Leite TG, Graça DS, Andrade VJ, Vale Filho VR. 2011. Desenvolvimento reprodutivo de tourinhos Gir selecionados para produção de leite. Arq Bras Med Vet Zootec, 63:12771286.

Martins VMV, Veiga TF, Martins E, Quadros SAF, 
Cardoso CP, Ribeiro JAR. 2009. Raça Crioula Lageana: o Esteio do Ontem, o Labor do Hoje e a Oportunidade do Amanhã. Lages, SC: ABCCL. pp. 341.

Menegassi SRO, Barcellos JOJ, Peripolli V, Pereira P, Borges JBS, Lampert VN. 2011. Measurement of scrotal circumference in beef bulls in Rio Grande do Sul. Arq Bras Med Vet Zootec, 63:87-93.

Menegassi SRO, Barcellos JOJ, Dias EA, Koetz C, Pereira GR, Peripolli V, McManus C, Canozzi MEA, Lopes FG. 2015. Scrotal infrared digital thermography as a predictor of seasonal effects on sperm traits in Braford bulls. Int. J Biometeorol, 59:357-364.

Moreira NH, Barbosa EA, Nascimento NV, Juliano RS, Abreu UGP, Ramos AF. 2016. Influência sazonal sobre o perfil seminal e congelabilidade do sêmen de touros pantaneiros. Cienc Anim Bras, 17:60-69.

Moura AAA, Rodrigues GC, Filho RM. 2002. Desenvolvimento ponderal e testicular, concentrações periféricas de testosterona e características de abate em touros da raça Nelore. Rev Bras Zootec, 31:934-943.

Regazzi AJ. 2000. Análise multivariada; notas de aula. Viçosa, MG: Departamento de Informática da Universidade Federal de Viçosa. (INF 766).

Siddiqui MAR, Bhattacharjee J, Das ZC, Islam MM, Islam MA, Haque MA, Parrish JJ, Shamsuddin M. 2008. Crossbred bull selection for bigger scrotum and shorter age at puberty with potentials for better quality semen. Reprod Domest Anim, 43:74-79.

Silva ASF. 2007. Maturidade sexual e congelabilidade do sêmen de tourinhos Gir-L, sob manejo alimentar estratégico. Belo Horizonte, MG, Brazil: Universidade Federal de Minas Gerais. Thesis.

Sosa JM, Senger PL, Reeves JJ. 2002. Evaluation of American Wagyu sires for scrotal circumference by age and body weight. J Anim Sci, 80:19-22.

Spritze Á, De Egito AA, Mariante AS, McManus C. 2003. Caracterização genética da raça bovina Crioulo Lageano por marcadores moleculares RAPD. Pesq Agrop Bras, 38:1157-1164.

Teixeira HCA, Nascimento N V, McManus C, Egito AA, Mariante AS, Ramos AF. 2011. Seasonal influence on semen traits and freezability from locally adapted Curraleiro bulls. Anim Reprod Sci, 125:56-61.

Torres-Júnior JRS, Henry M. 2005. Sexual development of Guzerat (Bos taurus indicus) bulls raised in a tropical region. Anim Reprod, 2:114-121.

Troconiz JF, Beltran J, Bastidas H, Larreal H, Bastidas P. 1991. Testicular development, body weight changes, puberty and semen traits of growing Guzerat and Nelore bulls. Theriogenology, 35:815-826.

Unanian MM, Emidio A, Feliciano D, McManus C, Cardoso P. 2000. Características biométricas testiculares para avaliação de touros zebuínos da raça Nelore. Rev Bras Zootec, 29:136-144.

Wolf FR, Almquist JO, Hale EB. 1965. Prepuberal behavior and pubertal characteristics of beef bulls on high nutrient allowance. J Anim Sci, 24:761-765.

Zanin A, Longhi-Wagner HM, Souza MLDR, Rieper M. 2009. Fitofisionomia das formações campestres do Campo dos Padres, Santa Catarina, Brasil. Insula Rev Bot, 38:42-57. 